\title{
The effect of the borehole diameter on the machining times in hard machining
}

János Kundrák, K. Gyáni, I. Deszpoth

University of Miskolc, Department of Production Engineering. E-mail: kundrak@uni-miskolc.hu

\begin{abstract}
When selecting the optional parameters in machining inner cylindrical surfaces the diameter of a borehole cannot be ignored. Also in finish precision machining, when fulfilling strict accuracy and surface quality parameters economically, it was presumed that the size of the borehole diameter has got an effect on the machining times of different procedures. Five different hard machining methods are compared here on the basis of time consumption. The common characteristic feature of the comparative investigations of different hard machining procedures is that their benchmark is always the traditional grinding. This time, too, that has been chosen. It is presented how the borehole diameter influences the machining times and the most economical procedure is proposed to be selected for given borehole diameter.
\end{abstract}

Keywords: hard machining, machining time, procedures

\section{Acknowledgement}

The research work has been realised as part of project TAMOP-4.2.1.B-10/2/KONV-2010-0001-in the frame of New Hungary Development Plan -, by the support of European Union, with the co-finance of European Social Found.

The work was presented by the support of the Hungarian Scientific Research Fund (Number of Agreement: OTKA K 78482), which the authors greatly appreciate.

\section{References}

[1] Knuefermann MMW - McKeown PA: A Model for Surface Roughness in Ultraprecision Hard Turning, Annals of the CIRP Vol.53/1/2004 pp.99-102

[2] KEVIN CHOU Y - SONG H: Tool nose radius effects on finish hard turning, Journal of Material Processing Technology, Vol.148/2/2004 pp.259-268

[3] BARRY J -BYRNE G: TEM study on the surface white layer in two turned hardened steels, Materials Science and Engineering, A325/2002 pp. 356-364

[4] KUNDRÁK J - GYÁNI K - BANA V: Roughness of ground and hard-turned surfaces on the basis of 3D parameters, International Journal of Advanced Manufacturing Technology Vol.38/1-2/2008 pp.110-119 DOI: 10.1007/s00170-007-1086-9

[5] KUNDRÁK J - GÁCSI Z - GYÁNI K et al.: X-ray diffraction investigation of white layer development in hardturned surfaces, International Journal of Advanced Manufacturing Technology Vol.62/5-8/2012 pp.457-469 DOI: $10.1007 / \mathrm{s} 00170-011-3811-7$

[6] SOOD R - GUO C - MALKIN S: Turning of Hardened Steels, Journal of Manufacturing Processes, Vol.2/3/2000 pp.187-193

[7] POULACHON G. - Bandyopadhyayb BP - Jawahir IS et al.: The influence of the microstructure of hardened steel workpiece on wear of PCBN cutting tools, Int. Journal of Machine Tools and Manufacture 43/2/2003 pp.139-144

[8] POULACHON G. - - Bandyopadhyayb BP - Jawahir IS et al.: Wear behavior of CBN tools while turning various hardened steels, Wear Vol.256/3-4/2004 pp. 302-310

[9] REMADNA M - RIGAL JF: Evolution during time of tool wear and cutting forces in case of hard turning with CBN inserts, Journal of Material Processing Technology Vol.178/1-3/2006 pp.67-75

[10] GRZESIK W: Influence of tools wear on surface roughness in hard turning using differently shaped ceramic tools, Wear Vol. 265/3-4/2008 pp.327-335

[11] RECH J - MOISAN A: Surface integrity in finish hard turning of case-hardened steels, Int. Journal of Machine Tools and Manufacture Vol.43/5/2003 pp.543-550

[12] KUNDRÁK J: Alternative machining procedures of hardened steels, Manufacturing Technology Vol.11/11/2011 pp.32-39, ISSN 1213-2489 
[13] KUNDRÁK J - Karpuschewski B - Gyáni K, et al.: Accuracy of hard turning, Journal of Materials Processing Technology Vol.202/1-3/2008 pp.328-338 DOI: 10.1016/j.jmatprotec.2007.09.056

[14] KAISER M: Hartfeinbearbeitung von einsatzgehärteter Stahl mit PKB Werkzeugen, IDR 1/1992 pp.24-33

[15] KÖNIG W - KLINGER M - LINK R: Machining hard materials with geometrically defined cutting edges, fields of applications and limitations, Annals of the CIRP Vol.39/1/1990 pp.61-64

[16] KLOCKE F - BRINKMEIER E - WEINERT K: Capability Profile of Hard Cutting and Grinding Process, Annals of the CIRP Vol.54/2/2005 pp.22-54

[17] FLEMING M - Wickman A: PCBN in the Automotive Industry, IDR 2/2006 pp.26-31

[18] Tönshoff HK - Arendt C - Ben Amor R: Cutting of Hardened Steel, Annals of the CIRP Vol.49/2/2000 pp.547566

[19] KUNDRÁK J - MAMALIS AG - MARKOPULOS A: Finishing of hardened boreholes: Grinding or Hard Cutting?, Materials and Manufacturing Processes Vol.19/6/2004 pp.979-993

[20] SAHIN Y - MOTORCU AR: Surface roughness model in machining hardened steel with cubic boron nitride cutting tool, Int. Journal of Refractory Metals and Hard Materials Vol.26/2/2008 pp.84-90

Paper number: M201232 